DOI: $10.17951 /$ rh.2019.48.103-118

\author{
Pavla Slavickova \\ (Palacký University, Olomouc) \\ https://orcid.org/0000-0001-9331-0961
}

\title{
The Influence of Bohemian and Moravian Land Law on the Content of the Land Ordinance of the Duchy of Opole and Racibórz: the Example of Family Law*
}

\author{
Wpływ czeskiego i morawskiego prawa o ziemi na treść Ordynacji Ziemskiej \\ Księstwa Opolsko-Raciborskiego na przykładzie prawa rodzinnego
}

\begin{abstract}
The aim of this contribution is to assess the extent of adoption of the Bohemian and Moravian land law in the crucial legal documents of 16th century Upper Silesia - the Land Ordinance of the Duchy of Opole and Racibórz, exemplified by the family law. The text is divided into three parts; the first part briefly summarised the process of codification in Bohemia and Moravia and in the Duchy of Opole and Racibórz, the second part analyses the form of the land ordinances and the third part focuses on the content of concrete legal institutes of family law.

Besides the above mentioned legal works, the comparison also takes into account the content of the Land Ordinance of the Duchy of Cieszyn and the crucial collection of municipal law, the Municipal Law Code of the Kingdom of Bohemia. The section related to guardianship of underage children, in particular, takes into account the possibility of the adoption from Roman law. Although many articles of the Land Ordinance of Opole and Racibórz contain similarities with the provisions of Bohemian and Moravian Land Ordinances, it would be a rash decision to talk about the adoption as only the principles are similar but not the formulations.

Rather than the adoption of Bohemian (and Moravian) law in Silesia, the adoption of the provisions originating in the Roman law, which was a common practice in the given period in Central Europe, seems more probable. In fact, the only proven direct adoption from Bohemian and Moravian land law in the law of the Duchy of Opole and Racibórz is the article Jak sirotci poručníky své kvitovati maji, taken from the Moravian Land Ordinance from 1535 and 1562, in which case the article is identical both in terms of the content and wording.
\end{abstract}

Affiliation: The paper has been prepared thanks to the support of Faculty of Arts, Palacký University, Olomouc, project No. FPVC2015/14. 
Key words: family law, Bohemia, Moravia, Silesia, Early Modern Time, land ordinances, legal history

Whereas unprecedented attention has been recently paid to Bohemian and Moravian land laws ${ }^{1}$, the land laws of Upper Silesia has been rather marginalised by researchers ${ }^{2}$ and there has been practically no research of the mutual relation of these two systems. However, the 1562 Land Ordinance of the Duchy of Opole and Racibórz is the most important collection of the land law of Upper Silesia ${ }^{3}$ and there are no doubts about its close relation to the Czech environment. In 1922, Jan Kapras", an important Czech law historian, published his thesis on the influence of Bohemian and Moravian land law on the formation of the law of the Duchy of Opole and Raciborz and Duchy of Cieszyn ${ }^{5}$. According to him, the adoption of the regulations and practices originating in the Bohemian land law in the law of the Duchy of Opole and Raciborz, as well as of the Duchy of Cieszyn, Duchy of Oświęcim and Zator and others had been the reality from the middle of the $15^{\text {th }}$ century; this was in relation to the

J. Janišová, D. Janiš, Moravská zemská zř̌izení a kodifikace zemského práva ve střední Evropě v 16. a na začátku 17. století, Praha 2006; Zemské zř́zení Markrabství moravského z roku 1516. Počátky kodifikace zemského práva na Moravě, Olomouc 2013; L. Jan, D. Janiš et al., Ad iustitiam et bonum commune. Proměny zemského práva v českých zemích ve středověku a raném novověku, Brno 2010; K. Malý, Tři studie o trestním právu v českých zemích v 17. a v proní polovině 18. století, Praha 2016; P. Kreuz, Zemské policejní prèedpisy v Českém království v druhé polovině 15. a na počátku 16. století, in: Poděbradská éra v zemích České koruny, Praha 2016, pp. 111-124; Moravské zemské zř́zení z roku 1516. K otázce vzniku zemských zř́zení v českých zemích na přelomu 15. a 16. století, in: Per saecula ad tempora nostra: sborník prací $k$ šedesátým narozeninám prof. Jaroslava Pánka, vol. 1, ed. D. Janiš, Praha 2007, pp. 153-162.

2 M.J. Ptak, Zemské právo Horního Slezska - stav bádání a badatelské perspektioy, in: Ad iustitiam et bonum commune: proměny zemského práva $v$ českých zemích ve středověku a raném novověku, Brno 2010, pp. 61-67; Statut zemski Ksiestw Opolskiego i Raciborskiego $i$ innych ziem do nich nalezacych, eds. O. Kniejski, R. Sekowski, Opole 2012; J. Bahlcke, Die Landesordnung in Schlesien im 16. und frühen 17. Jahrhundert zum Verhältnis von Gesetzgebund und Staatsentwicklung im Osten des ständischen Europa, 'Gegenkräfte: Studien zur politischen Kultur und Gesellschaftsstruktur Ostmitteleuropas in der Frühen Neuzeit' 2015, 31, pp. 56-67; L. Bobková, Zemská zř́zení a zemské stavy v Horní a Dolní Lužici v 16. století, in: Vladislavské zř́zení zemské a počátky ústavního zř́zení v českých zemích 1500-1619, Praha 2001, pp. 165-191; E. Šefčík, Boje o zemské zřizeni těšinské z konce 16. století, 'Vlastivědný věstník moravský' 1994, 46, 1, pp. 16-25; R. Jež, Prameny ke sporům o těšínské zemské zř́izení z poslední třetiny 16. století, 'Práce a studie Muzea Beskyd' 2008, 20, pp. 268-304.

3 M.J. Ptak, op. cit., p. 63.

4 Among others: J. Kapras, Právní dějiny koruny české, Praha 1913; idem, Přehled právních dějin zemí české koruny, Praha 1930; idem, Z dějin českého Slezska, Praha 1922.

5 Idem, Zemská zř́zení opolsko-ratibořské a těšinské, in: Sborník věd právních a státních, 22, Praha 1922, pp. 243-265. 
annexation of this territory to the Czech lands after the Hussite wars ${ }^{6}$. This process culminated in the $16^{\text {th }}$ century where particularly the Bohemian land law influenced the content of the Privilege of the Duchy of Opole and Raciborz from 1531, which became the basis for the formation of the Land Ordinance of this Duchy in 1562, and the Great Privilege of Cieszyn from 1572, which was followed by the Land Ordinance of Cieszyn in $1573^{7}$. The aim of this article is to compare the content of the Land Ordinance of the Duchy of Opole and Raciborz with the content of the Bohemian and Moravian land law from the same period, to assess the closeness of the content of these legal documents and, last but not least, to confirm or disprove the thesis of Kapras.

The period after the Hussite Wars was especially important for forming and codifying Czech land law; although it happened under different circumstances than in the case of the Silesian duchies. Increasing tension between both nobility estates and the municipal estate, which significantly strengthened its position not only on the economic but also the political level, brought all involved parties to the common interest to record in writing the positive law in order to secure the achieved position. Although the more powerful nobility finally took the initiative and enforced the Land Ordinance in wording unfavourable for the municipal estate ${ }^{8}$, the so-called Vladislavské zrrízení zemské (Vladislav's Land Ordinance), approved by the Bohemian Provincial Diet in 1500, represented the key moment in the development of the land law in the Kingdom of Bohemia'. Turbulent circumstances of the creation of the code fundamentally influenced its content, which had to be changed repeatedly and amended with respect to the needs of the continuously developing estate state. Although, by 1530, a part of this new Land Ordinance had already been published in an amended version and, shortly after that, a decision was made to revise, or more precisely to create, a new version of the Land Ordinance for Bohemia. This new version, which had been fundamentally revised and the system improved, was published in $1549^{10}$. However, in the $16^{\text {th }}$

6 Idem, Veliké privilegium knižectví Opolsko-Ratibořského, in: Sborník věd právních a státních, 12, Praha 1912, pp. 395-412.

7 Zemské zřízení těšinského knižectví z konce 16. století (Edice), ed. E. Šefčík, Český Těšín 2001.

8 But we can get the picture of the land law favourable for the municipality estate from the content of the work of Viktorín Kornel of Všehrdy O práviech, o súdech $i$ dskách země české knihy devatery (Nine books about law, courts and tables of the Bohemian land, finalised in 1499).

9 Vladislavské zř́zení zemské a navazující prameny (Svatováclavská smlouva a Zřizení o ručnicích). Edice, eds. P. Kreuz, I. Martinovský, Praha 2007.

10 K. Malý et al., Dějiny českého a československého práva do roku 1945, Praha 2003, p. 102. 
century, neither of these versions of the Land Ordinance of Bohemia were spared of changes. But these changes, specifically in the new edition from 1564, were insignificant in terms of content and affected mainly its form ${ }^{11}$. Unlike the Bohemian law, which had been in existence since the Middle Ages, the Moravian law had been based on Landfrieden, the oldest of them was from 1388 and the others were regularly concluded throughout the entirety of the $15^{\text {th }}$ and $16^{\text {th }}$ centuries. Important printed resolutions of Diet were also called the land ordinances. These documents were usually without the approval of the ruler though. Since the $1520 \mathrm{~s}$ the Moravian estates had also been striving for a codification of Moravian land law but they achieved their goal no earlier than in $1535^{12}$. This first Moravian Land Ordinance contained only procedural law and, besides the aforementioned Landfrieden, relied on, and in practice often used, the legal books kniha Tovačovská (Book of Tovačovský) ${ }^{13}$ and kniha Drnovská (Book of Drnovsk $\left.y^{14}\right)^{14}$. In terms of content, the second Moravian Land Ordinance from 1545 was more complete ${ }^{15}$. However, in 1562, instead of publishing a high-quality revision of the original version, only an amended version of the 1535 edition was published ${ }^{16}$.

The creation of the Duchy of Opole and Racibórz in 1521, which unified a significant part of the territory of Upper Silesia, was also the crucial moment in the process of law unification and encouraged the codification efforts. The decisive moment for the creation of the Land Ordinance of the Duchy of Opole and Racibórz was the publication of the already mentioned Land Privilege of Jan II the Good, the last of the Piasts of Opole, Głogów and Racibórz, which occurred in 1531. The Land Ordinance of Opole and Racibórz from 1562 became absolutely the first land law codification of its kind in Upper Silesia ${ }^{17}$. It regulated the existence and functioning of fundamental provincial institutions in this duchy; together with the

11 Zemská zřízení království českého 16. věku, eds. J. Jireček, H. Jireček, Praha 1882 (the book includes edition of Bohemian Land Ordinance from 1549).

12 Zemské zř́izení moravské z roku 1535 spolu s tiskem z roku 1562 nově vydaným, ed. F. Čáda, Praha 1937.

13 Kniha Tovačovská aneb Pana Ctibora z Cimburka a z Tovačova Pamět obyčejů, rádů, zoyklostí starodávných a ř́zení práva zemského v Mar. Mor. Kritické vydání, ed. V. Brandl, Brno 1868.

14 Idem, Kniha drnovská, Brno 1868.

15 Práva a zř́zení Markrabství moravského z roku 1545 (pokus moravských stavů o revizi zemského zř́zení), ed. D. Janiš, Brno 2005.

16 For more about the last Moravian Land Ordinance before the Thirty Years' War see Zřizení zemské Markrabství moravského z roku 1604, ed. J. Janišová, Praha 2005.

17 Zržijzenij Zemské Knijžetstwij Oppolského, a Ratiborského, u giných Kraguow k nim prijslussegijcých, wytisstěno w Nysy: v Ignatiusa Schubartha, 1671. 
procedural law, this area represents the biggest part of the document; the same as in the aforementioned Bohemian and Moravian land ordinances. Compared to this, family law does not directly take centre stage but we can still find a whole range of articles regulating this area. Specifically, the Ordinance of Opole and Racibórz regulates 23 articles in the matters of dowries (fol. $9 \mathrm{v}$ to $13 \mathrm{r}$ ) which are followed by another three articles regulating the status of orphaned girls (fol. $13 \mathrm{r}$ to $14 \mathrm{r}$ ) and in eight articles the matters related to guardianship and testaments (fol. $14 \mathrm{v}$ to $16 \mathrm{r}$ ) to which belong the section of 13 articles describing the matters of orphans (fol. 16r to 18r). These legal regulations are followed by other articles related to the law of succession, especially the section called Dily statkuov (Shares of Property, fol. 18r to 20v, seven articles in total) and the sections on associations and sale of inheritance (fol. $20 \mathrm{v}$ to $21 \mathrm{r}$, two articles per section). The Land Ordinance of Cieszyn from 1573 has a similar structure, and in the same way as the Ordinance of Opole and Racibórz, the Ordinance of Cieszyn lacks a designated part dealing directly with family law as well ${ }^{18}$. The chapter $O$ véních (On dowries) has 19 articles, the following section $O$ dcerách osiřelych (On orphan daughters) has the same three articles, the chapter $O$ testamentu a poručenství (On testaments and guardianship) has six articles and the section $O$ sirotcich (On orphans) has 14 articles. The regulations of the law of succession are supplemented by the chapters Díly statkưv, Spolky a Prodej dédictví (Shares of Property, Associations and Sale of inheritance) with 18 articles in total. The structure and extent of these chapters had remained unchanged until after the revision and new edition of this land ordinance in $1592^{19}$.

As for the family law in the Bohemian Land Ordinance from 1549 and 1564, the articles can be found scattered almost entirely throughout its content and only exceptionally are grouped in thematically related chapters $^{20}$. The matters of guardianship are regulated in the chapter O sirotcích a poručnících a o poručenství (On orphans and guardians, and on guardianship), which consists of articles F11 to F25. Dowries and the related matters are dealt with in articles S 33 to T 5 which are followed by the chapter $O$ mužích a ženách (On husbands and wives, art. T 6 to T 12). However, the regulations related to underage children can also be found in some other parts, especially in the sections $O$ rozdilych (On disputes, articles F 26 to F 39), O kšaftích a zápisích nápadních (On testaments and

18 Zemské zrízení těšinského knižectví, pp. 18-57.

19 Ibidem, pp. 59-97.

20 České zemské zrízení z roku 1549 (Bohemian Land Ordinance from 1549); Zemská zř́zení království českého 16. věku, eds. J. Jireček, H. Jireček, Praha 1882. 
contracts of inheritance, articles F 1 to F 10) and O zástavách a výplatách dědin dědičných i zápisných (On the guaranty and payment of property inherited and bequeathed, articles S 25 to S 32). In the Moravian Land Ordinance from 1535 and 1562 the matters of orphans are regulated in particular in articles 79 to 82 (O sirotcích od koho opatrováni býti mají, O prodaji statku sirotčího, Jak sirotci poručníky své kvitovati mají and O poručenství, kterak se ř́diti má) and in article 105 (O sirotčích penězích). Also articles 83 and 84 are concerned with the governance of orphan children's property (Bratr starší mladšímu statku utráceti nemá and Aby statek od rodu neodšel) and matters of the property of illegitimate children are regulated by article 85 (O pankharty). The matters of dowries are regulated especially by articles 120 to 129 (O věnných právích, Co panně odvěněno býti má, Jak se věna opatrují, O nápadích věnných and other) which are followed briefly by formulated articles on the law of succession (articles 130 to 132).

As is apparent, none of the mentioned codices regulates family law as a separate legal discipline. The information related to these matters is, in fact, scattered throughout the whole content of the land ordinances and the regulation of some matters in the context of related matters (e.g. in procedural law) is not an exception. This applies, for example, to the rights and duties of children but also to parental responsibility and the like. Identically, all land ordinances focus in particular on guardianship of underage children in general, whether in relation to a dowry or the inheritance of (illegitimate) offspring. These legal regulations don't usually address personal relations between family members, which is typical for this period, and similarly, we cannot find the definition of the term 'family' or the matters related to matrimony in these regulations, as these belonged to the canon law ${ }^{21}$. In terms of extent, in comparison with the Moravian and especially Bohemian family law, the norms of Silesian land ordinance are briefer but with respect to total volume and character of the Land Ordinance of Opole and Racibórz, the extent of the contained family law is unusually big in comparison to other documents. Similarly, the wording of the articles in Bohemian and Moravian land law, as shown in the comparison, does not have the quality of the wording of articles in the Ordinance of Opole and Racibórz, especially in terms of the abstraction of individual legal norms. Unlike the case of both Silesian land ordinances, the taxonomy of Bohemian Land Ordinance is noticeably worse, which probably originates from a significantly larger number of articles; the arrangement of which probably caused the authors some difficulties.

21 In detail described in P. Slavíčková, Právní ochrana dětí v období proních kodifikací, Praha 2012, pp. 36-77. 
When looking at the content of the norms in more depth, we can say that as for the institute of dowries, none of the analysed land ordinances deal with it in a significantly systematic way. At the beginning of the chapter of the Land Ordinance of Opole and Racibórz as well as in the Land Ordinance of Cieszyn, there is an article stating that dowry matters are governed by marriage articles which were officially sealed and deposited in the office ${ }^{22}$. However, immediately in the subsequent article, both documents diverge in terms of the content. According to the Land Ordinance of Opole and Racibórz, the dowry of the girl entering into marriage is supposed to be increased by the husband-to-be adding twice as much. Thus, if the girl has had brought 100 threescores, according to the old-time custom, the husband was supposed to provide another 200 threescores. This institute of the dowry (obvěnění) is typical for the Czech environment in which its autochthonous origin probably lies ${ }^{23}$, however not within the land law (before 1627 found only in the works of Viktorín Kornel of Všehrdy $)^{24}$ but in the municipal law. This legal institute entered the Bohemian land law from the crucial 1579 municipal law code Práva městská Královstuí českého (Municipal law code of the Kingdom of Bohemia) of Pavel Kristián of Koldín ${ }^{25}$, from where it was subsequently adopted also in the later codifications of the land law, including Obnovené zrízení zemské (Renewed Land Ordinance) from 1627. On the contrary, the institute of obvěnění (dower) was well known in the Moravian land law. It had already appeared in the legal books Kniha tovačovská and Kniha drnovská26, and also in the subsequent land ordinances from 1535, 1562 and 1604. But paradoxically, it disappeared from Moravian Obnovené zř́zení zemské (Renewed Land Ordinance) ${ }^{27}$. Likewise, this article is missing in all editions of the Land Ordinance of the Duchy of Cieszyn. Therefore, when speaking of adoption of the above-stated article in the Land Ordinance of Opole

22 Zržijzenij Zemské Knijžetstwij Oppolského, a Ratiborského, article I, fol. 9v (excerpt). Compare: 'Věna všeljaké, podle smluv svatebních zpečetěných, jenž se do kanceláře podávají, pečetí Jeho Milosti knížecí stvrzené a na statcích svobodných, prve nikomu nezavedených dělány býti mají. Zemské zř́izeni těšinského knižectví, art. I, p. 29.

23 J. Kapras, Manželské právo majetkové dle českého práva zemského, Praha 1908.

24 See footnote no. 9. Edition: O právích země české knihy devatery M. Viktorina ze Všehrd, ed. H. Jireček, Praha 1874.

25 Práva městská Království českého. Edice s komentářm, eds. K. Malý et al., Praha 2013.

26 Legal books containing Moravian land law drawn up upon a private initiative, which were used in Moravia at Moravian Land Court until drawing up of the Land Ordinance and in the case of the Book of Drnovice even after it. Kniha drnovská; idem, Kniha Tovačovská.

27 Kniha Tovačovská, p. 78; Moravské zemské zřizení z roku 1535, čl. LXXXVIII; Moravské zemské zřízení z roku 1562, čl. 121; Zřízení zemské Markrabství moravského z roku 1604, ed. J. Janišová, Praha 2005, čl. LXXXII. 
and Racibórz, necessarily, it must have been adopted from the Moravian land law and not the Bohemian ${ }^{28}$.

Article 3 of the Land Ordinance of Opole and Racibórz allows the wife to choose her guardians of the dowry at her discretion: 'Když paní každá za vůli muže svého může sobě za poručníky a př́jemce věna jejího voliti dvú neb třech přátel svých, kdo se jí zdáti a líbiti bude a takoví poručníci mají do listu jejího věnného jmenovitě zapsáni býti' ${ }^{29}$. The exact wording of this article also appears in the Land Ordinance of the Duchy of Cieszyn but unlike in the Moravian land law, we will not find it in the Bohemian land law. The Moravian law states: 'A věrné ruky mají se v tom opatřiti a se němniti, dokudž jsú živi. Než když by umřel věrná ruka, jiný z přátel anebo kohož by ta paní sobě zvolila, má vepsán býti' ${ }^{30}$. Also, the following article, which relates to differentiation (vybytí) of the daughter's property from the property of her father, has identical wording in both Silesian land ordinances but the Bohemian and Moravian land ordinances did not address these matters. This so-called vybytí, vysazení, or vyrajdování was regulated in the Czech environment, in particular in the municipal law, both in the previously-mentioned Práva městská of Pavel Kristián of Koldín and in the law of Brno and Jihlava or of Saxony and Magdeburg. However, this was usually connected to the payment of another property share (besides the dowry) and this case is not mentioned in the Land Ordinance of Opole and Racibórz ${ }^{31}$.

In comparison to the Land Ordinance of Cieszyn, the Land Ordinance of Opole and Racibórz contains, in addition, articles XI, XVII, XX and $X X I$. The first of the afore-cited articles forbids the sale of the wife's dowry without her consent by the husband and subsequent provision in a different form, which is a generally accepted principle in the Czech environment. However, any article of similar wording cannot be found in

28 'A nic jináče než podle starodávný zvyklosti věna dělány býti mají, totiž proti jednomu stu dvě výš i méně podle velikosti posahu'. Zržijzenij Zemské Knijžetstwij Oppolského, a Ratiborského, art. II, fol. 10r. Also the following article in the Land Ordinance of Opole and Racibórz corresponds with the wording of Moravian land law or Bohemian municipal law: 'Pakližby který manželce své nadto výše co z lásky učiniti chtěl, toho moc míti má avšak aby co kanceláří stvrzeno bylo'. Zržijzenij Zemské Knijžetstwij Oppolského, a Ratiborského, art. III, fol. 10r.

29 ('Every lady may choose at her own will, with the consent of her husband, two or three persons as guardians and those shall be recorded in her dowry certificate'). Zržijzenij Zemské Knijžetstwij Oppolského, a Ratiborského, art. IV, fol. 10r.

30 ('The guardians should be appointed and not replaced until they die. In the case of a guardian's death, another person of the lady's own choice shall be appointed'). Moravské zemské zř́zení z roku 1535 and 1562, art. 122.

31 P. Slavíčková, Institut věna ve Všeobecném občanském zákoníku a předchozích právních předpisech, 'Acta Universitatis Brunensis, Iuridica' 2011, 393, pp. 184-194. 
the Bohemian Land Ordinance from 1549; only some similarities can be found in the provisions of article $\mathrm{T} 3^{32}$. A similar situation is in the case of article XVII according to which, after the death of the wife, the husband keeps the property given to him by her ${ }^{33}$. On the contrary, article XXI has almost identical wording to article S7 of the Bohemian Land Ordinance from 1549, which deals with so-called vznešení in the case when the girl was not provided with a dowry, 'tehdy což by po ní otec, bratr, strýc, neb poručník jmenoval, to věnu bude ten sám povinen, kdož jest je do domu a obytu svého zval a prínos udělal, dáti a zaplatiti' ${ }^{34}$. Another example of exceptional uniformity can be found in article XIX which is contained both in the Land Ordinance of Opole and Racibórz and of Cieszyn and is the literal transcript of article S 34 of the Bohemian Land Ordinance from 1549. The article literally states: 'Jest-li že by který bratr, jsa nedílný bratří svých, a zapsal-li by na dílu svém ženě své věno: tehdy umřel-li by prvé než by se rozdělili, že ona nemuož věnem svým sáhnauti veyš, než na díl muže svého, a ten díl v tomu věnu má držeti, až do splacení toho věna od dědicův nebo nápadníkuov. Než nedostalo-li by co jí věna na tom dílu: tehdy má k tomu hleděti, kdož jest jí vdával'35. In the Land Ordinance of Opole and Racibórz, the last sentence of the text forms a separate article numbered as article $\mathrm{XX}^{36}$.

Also, other abovementioned chapters containing the articles on family law have a similarly heterogeneous nature. Besides the regulations of the law of succession, which we leave aside for this moment, the legal books and first codifications of early modern times usually paid the biggest attention to the matters of orphans and guardianship. Identical to the previous case, there is an apparent content sameness in the Land Ordinance of Opole and Racibórz and of Cieszyn. However, it is problematic to consider the wording of these norms to be identical with the articles provided in the Bohemian Land Ordinance. Its role, and in the case of the institute of guardianship, we should not forget this fact, played in this case Roman law and adoption of its legal principles in the Central-European environment

32 České zemské zřízení z roku 1549, art. T 3, in: Zemská zřízení království českého 16. věku.

33 Zržijzenij Zemské Knijžetstwij Oppolského, a Ratiborského, art. IV, fol. 12r.

34 ('...whoever takes her for his wife is obliged to give her property in the same amount as the dowry given to her by her her father, brother, uncle, or guardian'). České zemské zrrízení z roku 1549, art. S 37 (excerpt), in: Zemská zřízení království českého 16. věku.

35 ('If a husband dies, who was in the state of co-ownership with his brothers and had used his share to complement his wife's dowry, then the wife has a claim on the property up to the maximum amount of her husband's share and the claim holds until it is paid off in full. Should her claim not be upheld, the wife shall appeal to the authority who married her'). Ibidem, art. S 34.

36 Zržijzenij Zemské Knijžetstwij Oppolského, a Ratiborského, art. XX, fol. 12v. 
The influence of Roman law is apparent, especially in the order in which the individuals were supposed to assume the guardianship of orphan children. According to the Land Ordinance of Opole and Racibórz, the first decisive instrument was the last will and testament of the father. When the father did not make his last will, then the guardianship of relatives was the second choice; the Ordinance literally speaks of the uncle; when there were several of them, then the oldest or the one chosen by the authority assumed the guardianship: 'Kdyby sirotci za živnosti otce poručníky opatřeni nebyli, $\mathrm{k}$ těm právo má přede všemi strýc, př́tel po meči nejbližší. Pak-li jsou dva neb více k tej blízkosti, tehdá nejstarší neb podle uvážení pana hejtmana a pánuov soudcí, který by se nejlépe $\mathrm{k}$ dobrému sirotčímu $\mathrm{k}$ tomu hodil' ${ }^{37}$. In this respect, there is an apparent difference between both Silesian land ordinances, and the Bohemian and Moravian environment where the grandfather was considered the closest relative, then the adult brother and only then the uncle. Even guardianship by a widow, which is not present at all in the Land Ordinance of Opole and Racibórz, was not an exception in the Czech environment ${ }^{38}$. The third option was to appoint a guardian selected by public authority according to the law (dativi per inquisitionem judicis). In such a case the Silesian land ordinances stipulated the obligation to create an inventory of the deceased person's property. 'A jestliže by kdo bez poručenství z tohoto světa zšel, dítek let nemajících a statku po sobě nechajíc, aby hned pan hejtman ten statek podle pořádku zvyklého inventovati a sepsati nařídil a práteli těch sirotkův $\mathrm{k}$ sobě obeslal a podle zrrízení zemského aby statek opatrován byl, nařídil' ${ }^{39}$. This regulation is related to the provisions of Práva městská Královstuí českého ${ }^{40}$. However, the accounting of the orphan's inventory was not strange to the land law ${ }^{41}$. It was similar to the aforementioned municipal law, including older versions - for example municipal law of Brno and Jihlava, the Silesian land ordinances excluded 'squanderers'

37 ('If a father had not appointed guardians for his orphaned children while still alive, the guardian role then falls to their uncle or the closest male relative. If there are several such, then the governor and the judges shall appoint the eldest one or the one most suitable for this role'). Ibidem, art. I, fol. XVIv.

38 J. Kapras, Poručenství nad sirotky v právu českém se zřetelem $k$ právưm ř́mskému, německému a v Rakousích platnému, Praha 1904.

39 ('If a person of property dies without a testament and leaves behind children not yet of age, the governor shall make an inventory of the property according to the custom, summon the orphans' relatives, and order them to take care of the property according to the land law'). Zržijzenij Zemské Knijžetstwij Oppolského, a Ratiborského, art. VI, fol. 17r.

40 M. Pavel Kristián z Koldína Práva městská království českého a markrabství moravského, ed. J. Jireček, Praha 1876, čl. D XIII.

41 České zemské zřizení z roku 1549, art. D 11, in: Zemská zř́izení království českého 16. věku. 
from guardianship (the persons which, although closer by kinship to the orphans than others, had not proven their reliability ${ }^{42}$.

It is worth pointing out the fact that neither the Land Ordinance of Opole and Racibórz nor of Cieszyn contain any mention of the powerful paternal guardian which is typical for the Bohemian and Moravian environment. It was the guardian appointed by the father through the testament, which had, in comparison with other guardians, an exceptional authority over the persons under guardianship. In Bohemia and Moravia, this institute appears both in land ordinances and in municipal law, in which it was probably adopted right from the land law ${ }^{43}$.

Identically with Bohemian and Moravian land and municipal law, the Land Ordinance of Opole and Racibórz ordered the guarantee of orphan's property by the guardian. The guarantee of the property was the condition for assuming the position of guardian. If the guarantee was refused, the person lost the right of guardianship: 'Pakli by poručenství přijíti nechtěl a uručiti, tehdy k nápadu práva neměj, a poručenství na nejbližšího přítele spadni i nápad, kterýž by statek uručil ${ }^{44}$. We can also find similarities in other articles. For example, according to article VIII, it was not allowed that the guardian entered into any contract with an underage person under guardianship whose property the guardian guarded, unbeknown to public authorities: 'Žádný sirotka žádného, maje jej k moci svej, v jakomuž věc uvozovati ani s ním smlúvy činiti nemá bez vědomosti pana hejtmana a pánúv soudci' ${ }^{45}$. The municipal law code Práva městská Království českého also contained a similar prohibition and similar prohibitions are also

${ }^{42}$ 'Marnotratce, kteříž statek svuoj zmrhal a zbytkem utratil, poručníkem žádného statku sirotčího býti nemůže, by i nejbližší strýc a krví přirozený přítel byl, aneb i statek vručiti chtěl, pro zmatky a zavedení lidí, nemá jemu dopouštěno býti' the Land Ordinance of the Duchy of Opole and Racibórz: Zržijzenij Zemské Knijžetstwij Oppolského, a Ratiborského, art. VII, fol. 17r (excerpt). Also in the Land Ordinance of the Duchy of Cieszyn: E. Šefćík, Zemské zřizení těšinského knižectví, art. VIII, p. 35.

43 See e.g. Bohemian Land Ordinance from 1549: České zemské zřizení z roku 1549, art. F 11 and F 20, in: Zemská zřizení království českého 16. věku.

44 ('If a person does not want to accept the role and give due warranties as a guardian, then he forefeits his inheritance right to the property and the guardianship falls to the next nearest relative who is willing to give warranties'). Zržijzenij Zemské Knijžetstwij Oppolského, a Ratiborského, art. V, fol. 17r. Similarly e.g. Bohemian Land Ordinance from 1549: České zemské zřizení z roku 1549, art. F 21, in: Zemská zřizení království českého 16. věku and Práva městská Království českého (Municipal Law Code): M. Pavel Kristián z Koldina, art. D VII, par. III.

45 ('Orphan's guardian may not enter into contracts with the orphan without the knowledge of the governor and the judges'). Zržijzenij Zemské Knijžetstwij Oppolského, a Ratiborského, art. VIII, fol. XVIIv. In the Land Ordinance of Cieszyn also 'pokud let nemá a statek jemu moci jeho pouštěn není'. Zemské zř́izení těšinského knížectví, art. IX, p. 36. 
known from older cases of municipal law and other regulations of land ${ }^{l a w^{46}}$. A similar case is article X. According to this article, if an underage orphan entered into any contract or obligation related to its property under guardianship and this contract or obligation was disadvantageous to him, this transaction was regarded as void: 'Jestliže by který syn panského neb rytírského rodu komu statek jakýž kolivěk dal, aneb zavázal, dokudž by jeho prvé po otci svým v držení nebyl, takové datky, dary i zápisy nyní i na časy budúcí moci žádný nemají a nemohư' ${ }^{\prime 7}$.

In the same way as the Bohemian and Moravian land law, as well as the Land Ordinances of Opole and Racibórz, and of Cieszyn demanded the guardians to present the closing account, after the person under guardianship had attained his majority. Besides the closing account, the code Práva městská Království českého also required the guardians chosen by public authority to keep books on ongoing basis which had to be provided for annual inspection. The child was considered as major after reaching the age of 20, regardless of whether the child was a boy or girl. The public authority, in this case Landeshauptmann, could decide on lowering or increasing this age limit: 'Každý otec panského neb rytířského stavu maje syna neb syny poručenství o statku svými učiniti může a v svým poručenství zavázati, aby synom jeho neb synu statku postúpeno nebylo, leč by ke dvaceti letom přišel. A děvečky až by vdány byly. Avšak pan hejtman a páni soudce zemští toho moc míti podle potřeby let přičiniti $\mathrm{i}$ ujiti ${ }^{\prime 48}$. While the presentation of the closing account is also contained in article F 12 of the Bohemian Land Ordinance from 1549, the same age of majority for a boy and girl is unusual. The age of 20 is rather the upper limit stipulated by various legal regulations applicable in Bohemia and Moravia for males and females but also for estates ${ }^{49}$.

Although many articles of the Land Ordinance of Opole and Racibórz contain similarities with the provisions of Bohemian and Moravian Land Ordinances, it would be a rash decision to talk about the adoption as only the principles are similar but not the formulations. Rather than the

46 Práva městská Královstuí českého, art. D XXXII, in: M. Pavel Kristián z Koldína.

47 ('Should a lord's or knight's son donate or loan any family property before it is in his possession, such contracts shall be invalid'). Zržijzenij Zemské Knijžetstwij Oppolského, a Ratiborského, art. IX, fol. 17v.

48 ('Any lord or knight may require in his testament that his sons have reached twenty years of age and that his daughters have gotten married, before they take over the inheritance. However, the governor and judges may reduce or increase the required age as need be'). Zržijzenij Zemské Knijžetstwij Oppolského, a Ratiborského, art. X, fol. 17v.

49 Specifically, Municipal Law Code, chap. On young people: age of 18 for boy and age of 15 for girl. Usually, land ordinances distinguished the age based on estate membership, i.e. differently for peers, knights and subjects. 
adoption of Bohemian (and Moravian) law in Silesia, the adoption of the provisions originating in the Roman law, which was a common practice in the given period in Central Europe, seems more probable $\mathrm{e}^{50}$. In fact, the only proven adoption can be considered the article which is contained both in the Land ordinance of Opole and Racibórz and also in the Land Ordinance of Cieszyn. It specifically states: 'sirotci panského neb rytířského stavu, když by k letom přišli a poručníky neb strýce kvitovati chtěli, tehdy, aby poručníci aneb strýcové s sirotky před panem hejtmanem a pány soudci stáli a tu věc oznámili, že sirotci, již léta majíc, chtějí kvitovati poručníky aneb strýce. Tu pan hejtman a páni soudci tu věc slyšíc a rozvážíc, při čem ta věc státi má, rozkáží ${ }^{\prime 51}$. A literally identical article, titled Jak sirotci poručníky své kvitovati mají (How to request release of the inheritance from their guardians), can be found in the Moravian Land Ordinance from 1535 and $1562^{52}$. According to František Čáda, this text has its origin in the resolution of Moravian Provincial Diet from the $6^{\text {th }}$ of January 1520 and, although it was also later changed by resolution of the Diet, the codifiers kept its first version which also appeared in the revised version of the Book of Tovačovský and the Book of Drnovice ${ }^{53}$.

To summarise the above, first of all, we have to point out the brevity of the sections regulating relevant legal institutes in the Land Ordinance of Opole and Racibórz in comparison with Bohemian and Moravian land and municipal law. For example, in the case of guardianship of underage person, the articles related to legal disputes lodged by the guardians on behalf of the persons under guardianship and the provisions on payment of related costs are missing. Furthermore, the status of the widow is not mentioned anywhere, not to speak of the separation of the upbringing of the child from the administration of the child's property. The situations where the guardian fails in his duty or even dies are unregulated. It is not clear whether it is possible for the position of the guardian to be assumed by several persons at the same time or whether it is forbidden. Generally speaking, both sections related to dowry and guardianship show certain archaic elements, especially in comparison with municipal law; however, this can also be

50 M. Boháček, Řimské právní proky v právní knize brněnského písaře Jana, Praha 1924.

51 ('...when lord's or knight's orphans come of age and want their guardians to release the inheritance they need to come all together before the governor and the judges and make an announcement. The governor and the judges shall consider this request and validate it accordingly'). Zržijzenij Zemské Knijžetstwij Oppolského, a Ratiborského, art. XII, fol. 18r. Compare with the Land Ordinance of the Duchy of Cieszyn: Zemské zřizení těšinského knížectví, art. XIII, p. 36.

${ }^{52}$ Moravské zemské zř́zení z roku 1535, art. 81 of unabridged version, in: Zemské zřizení moravské z roku 1535.

53 Ibidem, p. 92. 
said about the Bohemian and Moravian land law in comparison with the municipal legal code Práva městská Království českého. No significant change is seen when comparing the provisions on dowry, which is generally more traditional and also a more conservative part of the family law, with the institute of guardianship which, as was mentioned, was usually very open to adoption from Roman law. However, we cannot confirm the key thesis of Jan Kapras, which has been presented at the beginning of this article, that the Bohemian Land Ordinance was the model for codification of the Land Ordinance of the Duchy of Opole and Racibórz. In family law of the Land Ordinance of Opole and Racibórz we rather find the articles originating in the Moravian land law than in the Bohemian land law. However, these cases are only random excerpts and we cannot talk about a systemic adoption of the regulation of these matters.

\section{REFERENCES}

\section{Published sources}

Janiš D., Moravské zemské zrrizení z roku 1516. Kotázce vzniku zemských zř́zení v českých zemích na přelomu 15. a 16. století, in: Per saecula ad tempora nostra: sborník prací k šedesátým narozeninám prof. Jaroslava Pánka, vol. 1, eds. J. Mikulec, M. Polívka, Praha 2007.

Kniha drnovská, ed. V. Brandl, Brno 1868.

Kniha Tovačovská aneb Pana Ctibora z Cimburka a z Tovačova Pamět’ obyčejů, řádů, zvyklostí starodávných a řizení práva zemského v Mar. Mor. Kritické vydání, ed. V. Brandl, Brno 1868.

M. Pavel Kristián z Koldína Práva městská království českého a markrabství moravského, ed. Jireček, Praha 1876.

O právích země české knihy devatery M. Viktorina ze Všehrd, ed. H. Jireček, Praha 1874.

Práva a zř́zení Markrabství moravského z roku 1545 (pokus moravských stavi̊ o revizi zemského zřizení), ed. D. Janiš, Brno 2005.

Práva městská Království českého. Edice s komentářem, eds. K. Malý et al., Praha 2013.

Statut zemski Ksiestw Opolskiego i Raciborskiego i innych ziem do nich nalezacych, eds. O. Kniejski, R. Sekowski, Opole 2012.

Vladislavské zř́zení zemské a navazující prameny (Svatováclavská smlouva a Zř́zení o ručnicích). Edice, eds. P. Kreuz, I. Martinovský, Praha 2007.

Zemská zřizení království českého 16. věku, eds. J. Jireček, H. Jireček, Praha 1882.

Zemské zrrízení Markrabství moravského z roku 1516. Počátky kodifikace zemského práva na Moravě, ed. J. Janišová, Olomouc 2013.

Zemské zř́zení moravské z roku 1535 spolu s tiskem z roku 1562 nově vydaným, ed. F. Čáda, Praha 1937.

Zemské zřizení těšinského knížectví z konce 16. století (Edice), ed. E. Šefčík, Český Těšín 2001.

Zržijzenij Zemské Knijžetstwij Oppolského, a Ratiborského, u giných Kraguow $k$ nim prijslussegijcých, wytisstěno w Nysy: v Ignatiusa Schubartha, 1671.

Zř́zení zemské Markrabstuí moravského z roku 1604, ed. J. Janišová, Praha 2005.

\section{Studies}

Bahlcke J., Die Landesordnung in Schlesien im 16. und frühen 17. Jahrhundert zum Verhältnis von Gesetzgebund und Staatsentwicklung im Osten des ständischen Europa, 'Gegenkräf- 
te: Studien zur politischen Kultur und Gesellschaftsstruktur Ostmitteleuropas in der Frühen Neuzeit' 2015, 31.

Bobková L., Zemská zř̌izení a zemské stavy v Horní a Dolní Lužici v 16. Století, in: Vladislavské zř́zení zemské a počátky ústavního zřizení v českých zemích 1500-1619, Praha 2001.

Boháček M., Ǩimské právní proky v právní knize brněnského písaře Jana, Praha 1924.

Jan L., Janiš D. et al., Ad iustitiam et bonum commune. Proměny zemského práva v českých zemích ve středověku a raném novověku, Brno 2010.

Janišová J., Janiš D., Moravská zemská zř́zení a kodifikace zemského práva ve střední Evropě v 16. a na začátku 17. století, Praha 2006.

Jež R., Prameny ke sporům o těšinské zemské zř́zení z poslední třetiny 16. stoleti, 'Práce a studie Muzea Beskyd' 2008, 20.

Kapras J., Manželské právo majetkové dle českého práva zemského, Praha 1908.

Kapras J., Právní dějiny koruny české, Praha 1913.

Kapras J., Poručenství nad sirotky v právu českém se zřetelem k právi̊m ř́mskému, německému av Rakousích platnému, Praha 1904.

Kapras J., Přehled právních dějin zemí české koruny, Praha 1930.

Kapras J., Z dějin českého Slezska, Praha 1922.

Kapras J., Veliké privilegium knížectví Opolsko-Ratibořského, in: Sborník věd právních a státnich, XII, Praha 1912.

Kapras J., Zemská zř́zení opolsko-ratibořské a těšinské, in: Sborník věd právních a státních, XXII, Praha 1922.

Kreuz P., Zemské policejní předpisy v Českém království v druhé polovině 15. a na počátku 16. století, in: Poděbradská éra v zemích České koruny, Praha 2016.

Malý K., Tři studie o trestním právu v českých zemích v 17. a v proní polovině 18. století, Praha 2016.

Malý K. et al., Dějiny českého a československého práva do roku 1945, Praha 2003.

Ptak M.J., Zemské právo Horního Slezska - stav bádání a badatelské perspektivy, in: Ad iustitiam et bonum commune: proměny zemského práva v českých zemích ve středověku a raném novověku, Brno 2010.

Slavíčková P., Institut věna ve Všeobecném občanském zákoníku a předchozích právních předpisech, 'Acta Universitatis Brunensis, Iuridica' 2011, 393.

Slavíčková P., Právní ochrana dětí v období proních kodifikací, Praha 2012.

Šefčík E., Boje o zemské zř́zení těšinské z konce 16. stoleti, 'Vlastivědný věstník moravský' $1994,46,1$.

\section{STRESZCZENIE}

W pracy podjęto próbę oceny zakresu zapożyczeń z czeskiego i morawskiego prawa o ziemi, obecnych w kluczowych dokumentach prawnych Górnego Śląska, uchwalonych w XVI w., mianowicie Ordynacji Ziemskiej Księstwa Opolsko-Raciborskiego, na przykładzie prawa rodzinnego. Artykuł składa się z trzech części. Pierwsza część opisuje proces kodyfikacji na terenie Moraw i Czech oraz w Księstwie Opolsko-Raciborskim. Druga część stanowi analizę formy ordynacji ziemskich. Trzecia część pracy kładzie nacisk na zawartość wybranych tekstów prawnych z zakresu prawa rodzinnego.

Ponadto, porównanie obejmuje zawartość Ordynacji Ziemskiej Księstwa Cieszyńskiego oraz kluczowy dla sprawy zbiór aktów prawa miejskiego Królestwa Czeskiego. Szczególną uwagę zwrócono na artykuły związane ze sprawowaniem opieki nad małoletnimi. Część poświęcona wspomnianej problematyce bierze pod uwagę możliwość adaptacji ustaw z prawa rzymskiego. Chociaż wiele przepisów zawartych w treści Ordynacji Ziem- 
skiej Księstwa Opolsko-Raciborskiego jest podobna do Ordynacji Ziemskiej w Czechach i na Morawach, stwierdzenie o przejęciu tychże praw może okazać się nazbyt śmiałe, jako że podobieństwo zauważalne jest jedynie w przypadku podstawowych zasad, nie zaś na poziomie sposobu formułowania tekstu.

Bardziej prawdopodobną wydaje się być możliwość, że rozwiązania zawarte w Ordynacji wywodziły się z prawa rzymskiego, co stanowiło powszechną praktykę na terenie ówczesnej Europy Środkowej. W rzeczywistości, jedynym udowodnionym przykładem bezpośredniego przejęcia czeskiego i morawskiego prawa o ziemi obecnego w zarządzeniach Księstwa Opolsko-Raciborskiego jest akt prawny Jak sirotci poručníky své kvitovati mají, zaczerpnięty z Ordynacji Ziemskiej Moraw z okresu 1535-1562, który jest identyczny zarówno pod względem treści, jak i sposobu sformułowania.

Słowa kluczowe: prawo rodzinne, Czechy, Morawy, Śląsk, wczesna nowożytność, Ordynacja Ziem, historia prawa

\section{ABOUT THE AUTHOR}

Pavla Slavíčková - Ph.D. has been an assistant professor at Palacký University in Olomouc (Czech Republic) since 2008. She focuses on legal and economics history, currently especially economic theories and accounting. She is an author of numerous articles both in Czech and international journals. She published several monographs, among others her book on the legal protection of children (Legal Protection of Children in the Period of the First Codifications) published in 2012 was very well accepted. Most recently she finished book named Accounting between Tradition and Rationality about the oldest accounting technique used in the Czech lands since the Middle Ages. She was a visiting scholar at number of scientific institutions, such as Institute of Urban History at Stockholm University (Sweden) and Institut für geschichtliche Rechtswissenschaft Ruprecht-Karls-Universität in Heidelberg (Germany). She is a member of the European Society of the History of Law. E-mail: pavla.slavickova@upol.cz. 